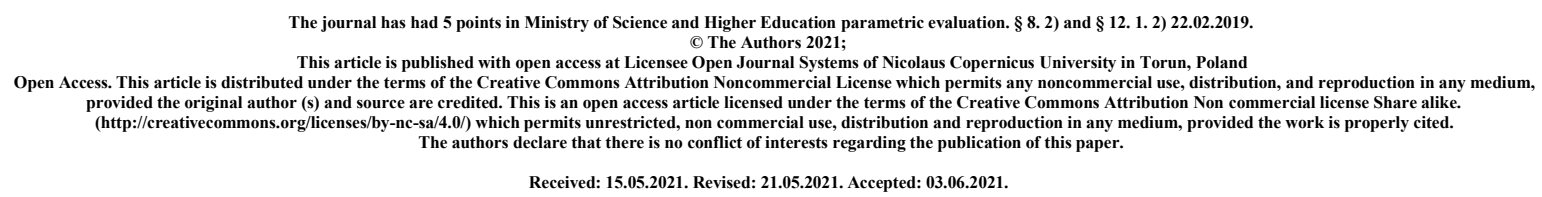

\title{
Stretching and injuries in men undertaking running training
}

\author{
${ }^{1}$ Zuzanna Piekorz (ORCID: 0000-0002-2881-1521), ${ }^{1}$ Damian Kwiatkowski, \\ ${ }^{1}$ Andrzej Lewandowski (ORCID: 0000-0003-0123-6608) \\ ${ }^{1}$ Department of Physiotherapy, Faculty of Health Sciences, Ludwik Rydygier Collegium Medicum in Bydgoszcz, \\ Nicolaus Copernicus University, Toruń, Poland
}

Corresponding author: Andrzej Lewandowski, Chair Department of Physiotherapy, Faculty of Health Sciences, Ludwik Rydygier Collegium Medicum in Bydgoszcz, Nicolaus Copernicus University, Toruń, ul. Świetojańska 20, 85-094 Bydgoszcz, Poland

Tel./ fax +48 52 585-54-16, fax: ext. 119,

E-mail: andrzej.lewandowski@cm.umk.pl

Acknowledgments:

The research was carried out as part of its statutory activities of the Department of Basic of Physical Culture, Faculty of Health Sciences, Ludwik Rydygier Collegium Medicum in Bydgoszcz, Nicolaus Copernicus University.

\section{Ethics:}

A permission to conduct this study was obtained from the Bioethics Committee of the Ludwik Rydygier Collegium Medicum of Nicolaus Copernicus University in Toruń (no. KB 787/2014). All men were informed about the purpose of the study, type and duration of the effort, and the possibility to withdraw from the study without giving any reason. Each potential participant granted a voluntary consent for participation in the study.

\section{Conflicts of Interest:}

The authors declare that there are no conflicts of interest.

Abstract word count: 339 
Text-only word count: 2570

Number of tables: 3 (tables)

Number of figures: 4 (figures)

Key words: running - men - running workout - competition - stretching - injuries

\section{Summary}

Introduction. Physical activity appears in men's life from the very beginning of their existence, however over last few decades it has become more popular as an amateur sport and recreation. One of the simplest form of physical activity considered as sport is running. Runners very often begin workouts thinking about improving their health but it comes with a risk of getting injured. There are however a lot of factors which can prevent injuries to occur. One of them is doing stretching exercises. The purpose of the study is to validate if stretching exercises can lower the risk of suffering an injury by men beginning a running workouts. In this study it was assumed that doing additional stretching exercises lowers the risk of suffering an injury and is common in people training long-distance running. Materials and Methods. 182 men who do running workouts in the city of Bydgoszcz were examined with the use of author's original questionnaire. It concerned sociodemographic data, running-related issues, stretching and the aspects of sports injuries. Statistics. Ordinal scales were analyzed with nonparametric rank tests, such as the Mann-Withney test, while the nominal scales were tested with nonparametric tests from the Pearson's chi-squared test group. Results. It was found that the largest group of runners are men aged about 32 years, doing running workouts as a part of amateur sport. Of all the subjects, $31 \%$ of runners declared the use of additional stretching training. People running with greater frequency and volume, expressed in kilometers, more often decide to undertake stretching exercises. $70 \%$ of tested athletes suffered a running-related injury. There was no significant effect of stretching on reducing the risk of injury to runners. Conclusions. Stretching is not very popular among running enthusiasts. Greater running experience and high training loads are factors that make runners decide to use additional stretching exercises more often. The lack of significant differences in the frequency of injuries of competitors using and not undertaking stretching does not allow an unequivocal assessment of its impact on reducing the risk of injury in runners.

\section{INTRODUCTION}

Over the past decades, physical activity, and especially running, has become very popular in Polish society. The undoubted advantage of this form of movement is its simplicity and the ability to implement it anywhere, anytime. As with any sporting activity, despite many unquestionable benefits [1,2], its intensive implementation is associated with the possibility of injury and even health risk [3,4]. Running enthusiasts often take them despite the presence of contraindications in the form of excessive weight, unrecognized or untreated cardiovascular 
diseases, especially hypertension and even diabetes. This statement is worrying because it is not just about runners. In our previous studies, we also found a lack of awareness of such contraindications in yoga practitioners [5]. It is common to repeat the same movements, which causes injury due to tissue overload [6]. The most common experiences of runners: patella-femoral conflict, shin splints, iliac tibial band syndrome, Achilles tendonitis, plantar fasciitis and chronic muscle damage [6-9]. It is known from earlier studies that relatively low awareness or its ignoring by amateur runners in the scope of proper assessment of their own health, methodology of running training, as well as the need to use wellness and specialized sports equipment contribute to their formation [10 -14]. The choice of surface and terrain to be used during training is also important for injury [15]. Therefore, in running, as in any other sport, trauma prevention is very important, one of which is additional stretching training stretching [16-18]. The scientific basis for the effects of stretching on the body was developed in the sixties and seventies of the last century, and practical exercise methods were developed in the late seventies. Over the years, numerous studies have been carried out on stretching, due to which it has become increasingly popular all over the world [17]. Therefore, the main purpose of the work is to assess the impact of these exercises on the occurrence of injuries in men undertaking running training. Another goal is to determine the type of injury and assess the stretching frequency by runners of varying levels of athletic sophistication. It was assumed that a small percentage of runners, especially beginners, perform a separate, targeted stretching training, and his undertaking reduces the incidence of injuries that are mainly caused by overloading the body.

\section{MATERIAL AND METHODS}

The study was conducted in 2016 and covered 182 men undertaking running trainings in recreational and sports areas in Bydgoszcz. Among the respondents were athletes of different ages, with different experience and advancement, undertaking training individually, as well as in smaller and larger groups. Inclusion criteria included men, runners' adulthood and a sense of good health.

We used our own questionnaire containing 22 questions with 15 closed single-choice questions, 4 closed multiple-choice questions and 4 open-ended questions. Questions 1-7 concerned the age of the respondents, driving experience, level of advancement, motivation and training habits. Questions 8-10 contained information about the participation of participants in mass runs, and another 5 concerned the use of warm-up and targeted stretching training. The last seven questions raised the problem of running-related injuries, their type and frequency, and the circumstances of their occurrence.

The collected material was divided by the lack or performance of stretching exercises and was developed using the STATISTICA 10 package, in which samples recorded on a quotient scale and having a normal distribution were analyzed using the Student's t-parameter test. Results that did not meet normal distribution and had a smaller group than 30-40 replicates were analyzed using nonparametric rank tests. The shape of the distribution was verified by the Shapiro-Wilk or Kolmogorov-Smirnov test. The results recorded on the nominal (qualitative) scale were presented as the frequency of occurrence of the analyzed phenomenon, and the quantitative parameters recorded on the ordinal and quotient scale were presented as minimum and maximum values, quartile values

as well as mean values and standard 
deviation. Nominal scales were analyzed using the non-parametric Paerson chi-square test, and ordinal scales using the non-parametric Mann-Whitney rank test. The significance coefficient $\alpha=0.05$ was used to verify all analyzes, which allowed to consider statistically significant variables at $\mathrm{p}<0.05$.

\section{RESULTS}

The studied group of runners are men of different ages (18-69 years, 32.6 \pm 10$)$ and differing in running experience $(0.1-30$ years, $3.7 \pm 3.7)$ and running injuries in 108 of them $(0,1-7$ years, $1.2 \pm 1.2$ ). Circumstances of occurrence and their types are presented in figures (Figures 1 and 2).

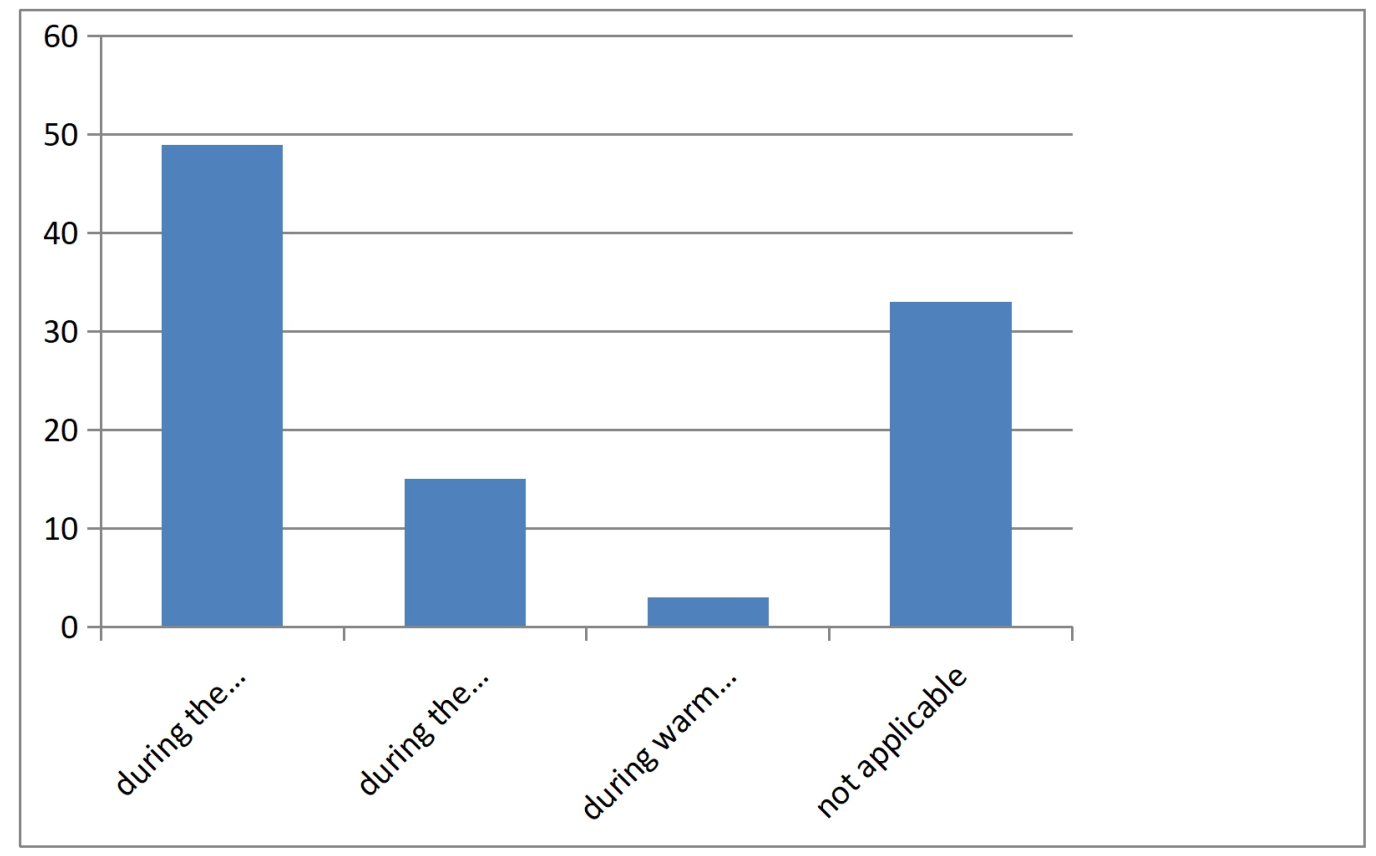

Figure 1. Graphical characteristics of the circumstances of the injury

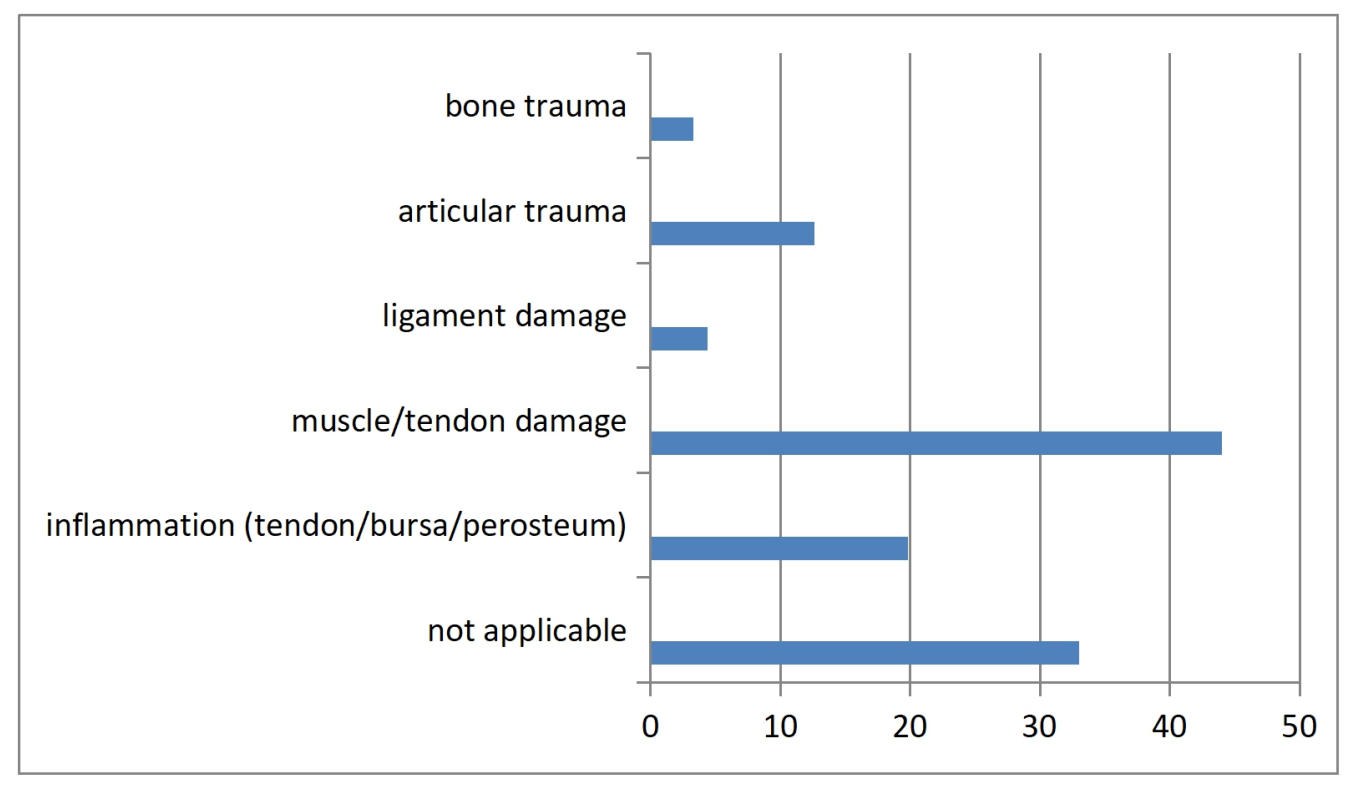


Figure 2. Graphical characteristics of the type of injury and its frequency

Among the respondents, amateur athletes dominate (57.0\%), 40\% practice running regularly, and only $4 \%$ of respondents sporadically. The largest part of the examined team $(50.0 \%)$ trains up to 3 times a week, slightly less $(38.0 \%)$ up to 5 times, and the lowest percentage is those who train more than 5 times or less than once a week (8, $0 \%$ and $4.0 \%)$. Most of them train without a training program or according to the author's program $(29.0 \%$ and $53.0 \%)$, and every tenth of them uses the knowledge of an experienced runner or trainer $(10.0 \%$ and $8.0 \%)$. The third part of the examined patients suffered an injury 1 or 2 times or did not suffer it at all, and the smallest percentage (4.0\%) declares their regular occurrence.

Teams of runners who do not perform stretching exercises and perform them (125 and 57 people) do not differ in age $(32.6 \pm 10.0$ and $32.4 \pm 10.1 ; \mathrm{p}=0.908)$ and the time of injury after starting training $(1.1 \pm 1.2$ and $1.3 \pm 1.3 ; \mathrm{p}=0.273)$, and their sports level does not differ. A large percentage of both groups conduct training in the form of amateur sport $(55.2 \%$ and $59.65 \%)$ or regular recreation $(40.0 \%$ and $40.35 \%)$, and sometimes it is undertaken only by a small team that does not stretch $(4,8 \% ; \mathrm{p}=0.237)$. Almost all respondents from both groups take part in mass runs $(92.0 \%$ and $92.98 \% ; \mathrm{p}=0.817)$. Teams of almost one-third of the runners from both groups did not suffer urac or were injured once, twice or three times, and the problem of frequently recurring running injuries concerns the smallest part of a few percent. The percentage of players of both groups who on the day of injury did not warm up and had a warm-up (Fig. 3 and 4) is similar and does not distinguish between two groups.

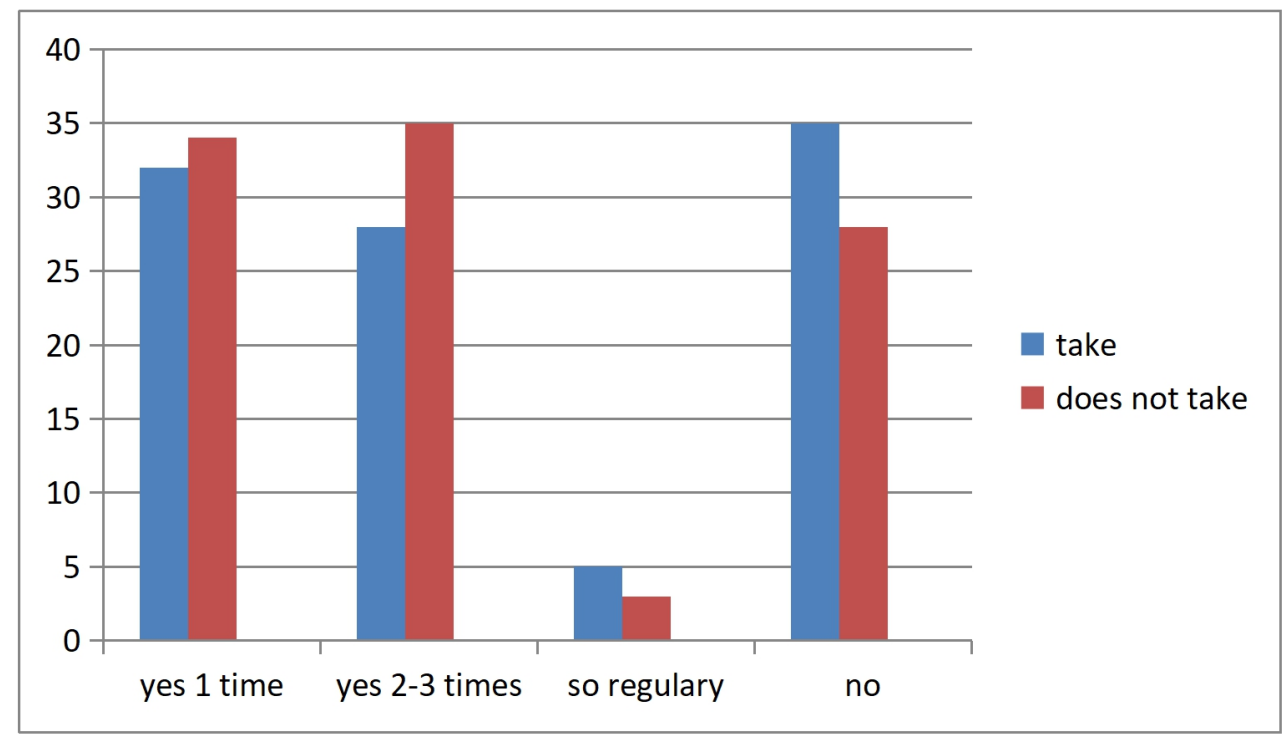

Figure 3. Graphical characteristics of the respondents' injury frequency, differentiated by the lack of or undertaking targeted stretching training 


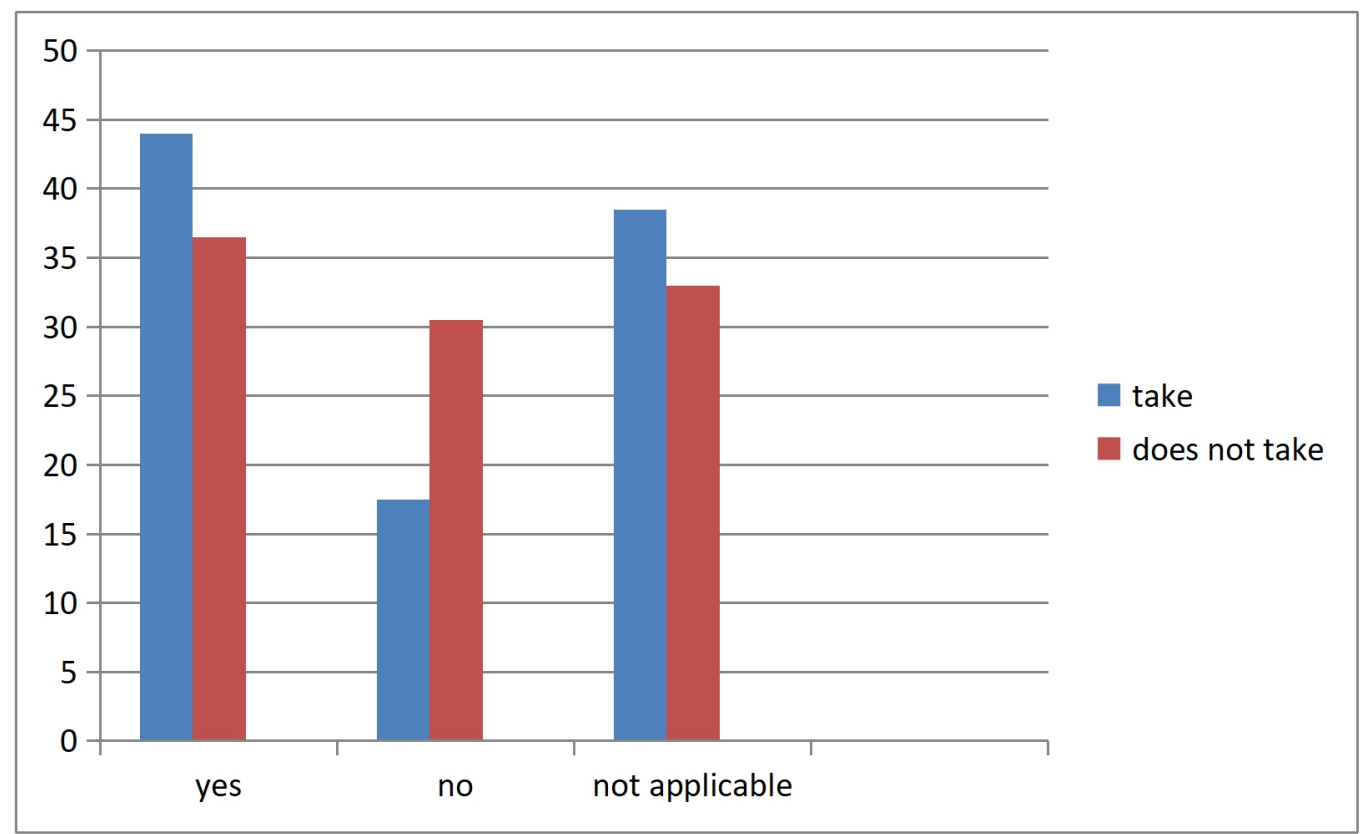

Figure 4. Graphical characteristics of the warm-up application on the day of the injury of the surveyed people, who differ in the absence or undertaking of targeted stretching training

The teams studied, however, differ in training experience, which is clearly longer among those who use stretching $(3.2 \pm 2.7$ and $4.9 \pm 5.0 ; p=0.005)$, as well as the frequency and volume of running training. Higher values of these determinants are characterized by a higher percentage share of members of this group of athletes, as shown in Table 1.

Table I. Comparative characteristics of the frequency and volume of training

\begin{tabular}{|c|c|c|c|c|c|}
\hline \multirow{3}{*}{ Category } & \multicolumn{4}{|c|}{ Additional stretching training } & \multirow{3}{*}{$\mathrm{p}$} \\
\hline & \multicolumn{2}{|c|}{ does not perform } & \multicolumn{2}{|c|}{ performs } & \\
\hline & $\mathrm{N}$ & $\%$ & $\mathrm{~N}$ & $\%$ & \\
\hline \multicolumn{6}{|c|}{ Weekly frequency of running trainings } \\
\hline 1 time & 7 & 5,60 & 1 & 1,75 & \multirow[b]{4}{*}{$0,006^{*}$} \\
\hline up to 3 times & 69 & 55,20 & 22 & 38,60 & \\
\hline up to 5 times & 42 & 33,60 & 27 & 47,37 & \\
\hline $5<$ & 7 & 5,60 & 7 & 12,28 & \\
\hline \multicolumn{6}{|c|}{ Weekly running training load $(\mathrm{km})$} \\
\hline $20>$ & 22 & 17,60 & 4 & 7,02 & \\
\hline $20-40$ & 58 & 46,40 & 22 & 38,60 & \\
\hline $40-60$ & 32 & 25,60 & 15 & 26,32 & \\
\hline $60-80$ & 5 & 4,00 & 5 & 8,77 & \\
\hline $80-100$ & 8 & 6,40 & 10 & 17,54 & \\
\hline
\end{tabular}




\begin{tabular}{|l|c|c|c|c|c|}
\hline $100<$ & - & - & 1 & 1,75 & $0,005^{*}$ \\
\hline
\end{tabular}

$*$ statistically significant difference, $\mathrm{p}<0.05$

They also differ in the way of training management $(p=0.031)$, which is implemented without a training plan by a higher percentage of non-stretching people (34.4\% and $15.79 \%)$. The largest percentage of people from both groups organize them independently $(51.2 \%$ and $56.41 \%$ ), and the smallest percentage of respondents use training plans prepared by more experienced runners $(8.0 \%$ and $15.79 \%)$ and trainers $(6,4$ and 12.28$)$. Competitors divided by taking and not applying stretching also differ in how they prepare themselves before training and competition, and also perform stretching exercises later. Higher trait values characterize a larger percentage of athletes using stretching. The numbers and results of the statistical assessment of percentage differences in the distribution of runners from both groups are presented in Tables 2 and 3.

Table II. Comparative characteristics of the warm-up time before training and competition

\begin{tabular}{|c|c|c|c|c|c|}
\hline \multirow{3}{*}{ Category } & \multicolumn{4}{|c|}{ Additional stretching training } & \multirow{3}{*}{$\mathrm{p}$} \\
\hline & \multicolumn{2}{|c|}{ does not perform } & \multicolumn{2}{|c|}{ performs } & \\
\hline & $\mathrm{N}$ & $\%$ & $\mathrm{~N}$ & $\%$ & \\
\hline \multicolumn{6}{|c|}{ Warming up before training } \\
\hline Lack & 21 & 16,80 & 3 & 5,26 & \multirow{4}{*}{$0,042 *$} \\
\hline occasionally & 42 & 33,60 & 14 & 24,56 & \\
\hline$<10 \min$ & 46 & 36,80 & 28 & 49,12 & \\
\hline$>10 \mathrm{mim}$ & 16 & 12,80 & 12 & 21,05 & \\
\hline \multicolumn{6}{|c|}{ warming up before the competition } \\
\hline Lack & - & - & - & - & \multirow{4}{*}{$0,021^{*}$} \\
\hline occasionally & 11 & 8,80 & - & - & \\
\hline$<10 \min$ & 58 & 46,40 & 24 & 42,11 & \\
\hline$>10 \mathrm{mim}$ & 49 & 39,20 & 29 & 50,88 & \\
\hline
\end{tabular}

$*$ statistically significant difference, $\mathrm{p}<0.05$ 
Table III. Comparative characteristics of performing stretching exercises after training and competition

\begin{tabular}{|l|c|c|c|c|c|}
\hline \multirow{2}{*}{ Category } & \multicolumn{4}{|c|}{ Additional stretching training } & \multirow{2}{*}{$\mathrm{p}$} \\
\cline { 2 - 5 } & does not perform & performs & \\
\cline { 2 - 5 } & $\mathrm{N}$ & $\%$ & $\mathrm{~N}$ & $\%$ & \\
\hline \multicolumn{4}{|c|}{ Applying stretching exercises after training } \\
\hline Yes & 53 & 42,40 & 39 & 68,42 & \\
\hline Occasionally & 51 & 40,80 & 14 & 24,56 & \multirow{2}{*}{$0,004^{*}$} \\
\hline No & 21 & 16,80 & 4 & 7,02 & \multirow{2}{*}{$0,015^{*}$} \\
\hline \multicolumn{5}{|c|}{ Performing stretching exercises after competitions } \\
\hline Yes & 42 & 33,60 & 32 & 56,14 & \\
\hline Occasionally & 45 & 36,00 & 16 & 28,07 & \\
\hline No & 30 & 24,00 & 5 & 8,77 & \\
\hline
\end{tabular}

* statistically significant difference, $\mathrm{p}<0.05$

\section{DISCUSSION}

The basic observations and statements resulting from the analysis of the developed material were reduced to the ones below and an attempt was made to develop tchem with reference to literature data and also own experience.

1. Running is a sport discipline, especially popular among middle-aged men who largely create their own training program.

2. Most men undertaking running training do not use additional targeted stretching training.

3. More experienced runners perform separate, targeted stretching training more often than beginners.

4. Undertaking targeted stretching training does not significantly affect the incidence of injuries that affect nearly $70 \%$ of men surveyed practicing long distance running.

5. The most common among long distance runners are injuries related to tissue overload.

The examined team of runners are people of different ages, which indirectly indicates that physical activity based on a simple, natural form of movement and not requiring specialized equipment, implemented both individually and as a team in almost anywhere, can be popular and effectively activate society. We find similar statements in many studies [3,19-21]. Numerous competitions organized for amateurs are not without significance in the popularization of running, which often do not place restrictions on the age of competitors, and the division into its categories creates the opportunity to compete with peers. This makes men more willing to start running trainings, especially since some mass runs also provide prizes for the oldest and youngest participant. In Poland, participation in mass runs does not require the presentation of a medical certificate of the absence of health contraindications to the implementation of the effort, which certainly positively affects the frequency and popularity of running. However, it creates potential threats, which, according to earlier research results of the participants of the Bydgoszcz half marathon, remain in the consciousness of just over half of the respondents [10]. The large shares of adult runners surveyed, treating running as an amateur sport, may indicate a desire to improve health and fitness or weight loss or reduce 
stress levels, described in numerous studies [1,2,22]. They may also result from the male need to compete and overcome the limits of their own abilities and testify to the growing popularity of running in Polish society.

In order to obtain the expected results, most of the runners surveyed undertake trainings 2 to 5 times a week, which contrasts with undertaking targeted stretching training only by the third of them. Thus, the hypothesis put forward at work about the low popularity of stretching among amateur runners seems to be confirmed, and also indicates insufficient awareness of the impact of regular stretching exercises on the human body. B. Anderson and M. Listkowski raised these problems in their works [16,17]. The situation found in current research may, however, result from the lack of time to perform additional training and little knowledge of amateur athletes about the causes of running injuries and the possibility of their prevention. For professional runners, the use of stretching exercises is an integral part of any workout, because their organisms must be optimally developed in each direction.

One of the research objectives was to assess the impact of age and experience of runners on undertaking separate, focused stretching training. Research results indicate that runners who use and do not use stretching have a similar average age. A large group of surveyed athletes close to the average age does not allow to clearly determine what effect age has on stretching. The factor that, according to the presented thesis, turned out to be important when undertaking this form of exercise is sports experience and sports level. Runners with more experience, high-frequency training and more difficult training decide on additional stretching training. Therefore, it should be assumed that knowledge in the field of training methodology and injury prevention for people starting their adventure with running is insufficient. This statement indirectly justifies the higher warm-up frequency in a group of runners performing a separate stretching workout.

According to another hypothesis adopted in the study, runners performing additional stretching training are less exposed to injury than competitors who do not use stretching. The observed difference is small and therefore it should be noted that the detailed characteristics of the stretching training undertaken have not been investigated in this article. It is difficult to determine its intensity, volume and quality, and thus preventive value. It is worth noting, however, that people using stretching run longer and more often and cover a greater number of kilometers, which increases the risk of injury. The impact of these factors on the occurrence of injuries has also been described and confirmed by other authors [2.6-9]. Stretching is the most common form of injury prevention recommended by professional trainers and sports injury specialists, but the relationship between the degree of muscle stretching and the risk of injury is still being discussed [23]. Swedish authors have shown that stretching reduces the risk of injury to players in many sports [17], which is not synonymous with the results of current research.

The presented studies also showed that trauma associated with tissue overload dominates in running sports, which is also confirmed by other authors [6-9]. These may also be further effects of other conditions or situations. In the area of the spine and lower limbs, injuries occur, e.g. in the case of weakening of stabilizing muscles [24]. Therefore, training errors have a large impact on the occurrence of injuries caused by overload, which can be observed in the analysis of the results regarding the circumstances and time of injury. Almost half of the runners surveyed suffered injuries during training, which is consistent with literature data 
$[2,8]$. However, it should be remembered that runners spend much more time training, and they run much more kilometers there than during competitions or warm-up, and also implement various forms of training there [25]. Of the respondents, as many as $70 \%$ of people were injured because of running at least once. This may be justified by the players' insufficient knowledge about injuries and their prevention. This is probably related to several years of running experience of a large proportion of runners surveyed and little use of the advice of professional trainers. On the other hand, many other causes can affect injuries, including other types of physical activity.

To sum up the results of conducted research, one should pay attention to potential limitations that may reduce their credibility. The obstacle to obtaining full credibility of the research can be the use of the author's questionnaire and the fact that only men from one environment and amateur running were included in the observation. The real picture of the problem raised in the work can also be affected by a short period of research, and thus a very limited size of the examined group. Therefore, the above observations require treating the formulated conclusions as the result of partial research, which due to the constantly growing interest in running should be continued.

Despite the limitations, however, we were able to create a general characteristic of an amateur runner who, according to the results of the study, is a middle-aged man with three years of training experience, training about 3 times a week and running up to 40 kilometers a week. This runner conducts training according to his plan, participates in organized mass runs, does not always carry out stretching training and at least once suffered a trauma associated with running.

\section{CONCLUSION}

Low level of athletic advancement and insufficient knowledge contribute to the low popularity of stretching among jogging enthusiasts, and the training period, sport level and use of heavy loads are factors determining additional stretching training. It seems, however, that it has no clear impact on reducing the risk of injury, and the warming and stretching exercises it contains used before training and competition allow you to successfully replace it. It can also be said that the injuries of runners, which are probably the main cause of overload, are largely caused by training errors, not the specificity of the movement used in this sport.

\section{REFERENCES}

1. Birch K, MacLaren D, George K. Fizjologia sportu. Krótkie wykłady. Wydawnictwo naukowe PWN SA, ISBN 978-83-01-15460-8, Warszawa 2008.

2. Maharam L.G. Biegaj zdrowo. Inne Spacery - Sembrador, ISBN 978-83-930794-6-9, Zielonka 2013.

3. Thomee R, Augustsson J, Karlsson J. Patellofemoral pain syndrome: A review of current issues. Sports Medicine, November 1999, 28 (4): 245-262.

4. Taunton J.E, Ryan M.B, Clement D.B. A retrospective case-control analysis of 2002 running injuries. British Journal of Sport Medicine 2002; 36: 95-101.

5. Piekorz Z, Bułatowicz I, Radzimińska A, Lewandowski A. Piekorz S. Wpływ treningu hata-jogi na wartości ciśnienia tętniczego i częstości tętna. Medical and Biological Sciences 2013; 27/2: 33-39. 
6. Benca E, Ziai P, von Skrbensky G, Ahmetović A, Windhager R, Krpo S. Running injuries. Medicinski zurnal 2013; 19 (4): 345-353.

7. Pinshaw R, Atlas V, Noakes T.D. The nature and response to therapy of 196 consecutive injuries seen at a runner's clinic. South African Medical Journal 1984; 65: 291-298.

8. Brent Brotzman S, Wilk K.E. Rehabilitacja ortopedyczna, tom 2. Elsevier Urban\&Partner, ISBN 978-83-7609-081-8, Wrocław 2008.

9. Di Caprio F, Buda R, Mosca M, Calabro A, Giannini S. Foot and lower limb diseases in runners assessment of risk factors. Journal of Sports Science and Medicine 2010; 9: 587-596.

10. Piekorz Z, Lewandowski A, Szarski K, Radzimińska A, Strojek K, Styczyńska H, Zukow

W. Kontuzje i urazy w świadomości biegaczy długodystansowych. Journal of Education, Health and Sport 2017; 7 (3): 143-152.

11. Del Coso J, Areces F, Salinero J.J, Gonzalez-Millan C, Abian-Vicen J, Soriano L, Ruiz D, Gallo C, Lara B, Calleja-Gonzalez J. Compression stockings do not improve muscular performance during a half-ironman triathlon race. European Journal of Applied Physiology 2014; 114: 587-595.

12. Hill J, Howatson G, vanSomeren K, Leeder J, Pedlar C. Compression garments abd recovery from exercise-induced muscle damage: a meta-analysis. British Journal of Sports Medicine 2014; 48: 1340-1346.

13. Pruscino C.L, Halson S, Hargreaves M. Effects of compression garments on recovery following intermittent exercise. European Journal of Applied Physiology 2013; 113: 15851596.

14. Michael J.S, Dogramaci S.N, Steel K.A, Graham K.S. What is the effect of compression garments on a balance task in female athletes?. Gait\&Posture 2014; 39: 804-809.

15. Lucas C.A. Iliotibial Band Friction Syndrome as Exhibited in Athletes. Journal of Athletic Training 1992; 27(3): 250-252.

16. Anderson B. Stretching czyli ćwiczenia rozciągające dla zwykłych śmiertelników oraz sportowców różnych dyscyplin. Zakład Narodowy imienia Ossolińskich - Wydawnictwo, ISBN 83-04-04361-0, Wrocław 1997.

17. Listkowski M. Stretching. Sprawność i zdrowie. Wydawnictwo Marian Listkowski, ISBN 83-902643-0-7, Łódź 1994.

18. Nonn-Wasztan S, Wójcik M. Zastosowanie stretchingu i jego form u tancerzy. Dysfunkcje narządu ruchu 2013; 4: 49-61.

19. Gallant JL, Pierrynowski MR. A therettical perspective on runnining-related injuries. Journal of the American Prdiatric Medical Association 2014; 104(2): 211-220.

20. Almonroeder T, Willsson JD, Kernozek TW. The Effect of Foot Strike Pattern on Achilles Tendon Load During Runing. Annales of Biomedical Engineerinf 2013; 41(8): 17581766.

21. Theisen D, Malisoux L, Genin J, Delattre N, Seil R, Urhausen A. Influence of midsole hardness of standard cushioned shoes on running-related injury risk. British Journal of Sport Medicine 2014; 48:371-376.

22. MacAuley D. ed. by. (2012) Oxford Handbook of Sport and Exercise Medicine. Oxford University Press, USA; 2nd Revised ed.

23. Witvrouw E, Mahieu N, Danneels L, McNair P. Stretching and Injury Prevention. An Obscure Relationship. Sports Medicine 2004; 34 (7): 443-449. 
24. Schmitz A, Russo K, Edwards L, Noehren B. Do novice runners have weak hips and bad running form?. Gait\&Posture 2014; 40: 82-86.

25. Zadpoor AA, Nikooyan AA. Modeling muscle activity to study the effects of footwear on the impact forces and vibrations of the human body during running. Journal of Biomechanics 2010;43:186-193. 